\title{
The Search for Educational Betterment in a Foreign Land: A Study of the North China Japanese Elementary School Principals' Conference
}

\author{
Mizuno Norihito
}

\begin{abstract}
Education for their children is one of the greatest concerns today among overseas Japanese residents, and so it was for overseas Japanese residents in the pre-Second World War period. Overseas Japanese educational institutions are faced with various problems today, as they were in the pre-war period. In 1926, the principals of the Japanese elementary schools, who were scattered across the Northern Chinese provinces, gathered in Beijing for the purpose of discussing educational and management issues. This marked the inauguration of the North China Elementary School Principals' Conference, which took place irregularly in different locations until the early 1940s. This article attempts to clarify what issues the conference discussed and how it tried to cope with them for the betterment of the education for Japanese children in a strange land.
\end{abstract}

Index Terms - Japan, history of education, sino-japanese relations.

\section{INTRODUCTION}

The history of Japanese overseas education can be divided into two phases. Japan's overseas expansion, especially after the victory in the Sino-Japanese War (1894-5), encouraged the outflow of sections of the Japanese population and the formation of overseas communities. The increase of overseas Japanese residents was accompanied by the increase of concerns about education for overseas Japanese children and the establishment of various ranks of educational institutions. The collapse of the Japanese colonial empire in 1945 completely extinguished the overseas Japanese communities and educational institutions, and it was not until the late 1950s that educational institutions for overseas Japanese children began to re-emerge and continued to increase throughout the period of the country's economic miracle and even after the burst of the economic bubble in the early 1990s [1].

Among those involved in overseas education, such as the officials of the Ministry of Education, Culture, Sports, Science and Technology (MEXT) and the steering committee members of the overseas Japanese schools, in recent years, some have deemed the post-Second World War Japanese overseas education to be at a "crossroads" or "turning point [2]." The Japanese Foreign Ministry recognizes the significance of overseas education in terms of Japanese success overseas [3]. However, both the Japanese education ministry and overseas Japanese educational institutions are

Manuscript received June 30, 2013; revised September 5, 2013.

Mizuno Norihito is with Akita International University, Akita-shi, Akita 010-1292 Japan (email: nmizuno@aiu.ac.jp). currently faced with various challenges. Some of these issues are ones they have chronically struggled with, and others have come about through changing local, domestic and international environments [4].

In the late $1920 \mathrm{~s}$, critical views of overseas education emerged over the state of education for Japanese children in China. One of the solutions which the local educational institutions for overseas Japanese children conceived of was to engage in communication between the institutions which were scattered over the vast land and to take cooperative concerted actions. In August 1926, the principals of the thirteen Japanese elementary schools located in northern Chinese provinces gathered in Beijing. This was the beginning of the North China Japanese School Principals' Conference (Hokushi Nihon Gakkocho Kaigi), which thereafter took place sporadically, though it was originally expected to do so annually, until the early 1940s. Although there has been some previous research into overseas Japanese educational institutions, including elementary schools, from the late nineteenth to the end of the Second World War, the history of Japanese overseas education during the modern period are still a relatively unexplored area. The same can be said of the state of research on Japanese educational institutions in China, and the North China Japanese Principals' Conference is one of those unexplored topics. This article will discuss what problems the overseas elementary schools were confronted with in the pre-1945 period and how they tried to overcome them by exploring what was discussed in the principals' conferences.

\section{JAPANESE RESIDENTS AND COMMUNITIES IN CHINA}

In the modern period, the increase of the Japanese population in China ran parallel with the country's economic and military penetration into its neighboring countries, and its beginnings can be traced back to the start of the 1870 s. Following the absence of communication with the West, except for Holland, for over two hundred years, Japan surrendered to Western gunboat policy and renounced the so-called Sakoku (National Isolation) policy in the $1850 \mathrm{~s}$. Less than two decades after that, the Meiji Restoration took place, and the Tokugawa bakufu (shogunate) (1603-1868) was overthrown by the anti-Tokugawa forces supporting the emperor. The Japanese population had continued to increase since the very beginning of the 1870 s but remained insignificant until the very end of the nineteenth century. As had Western precursors done so, a series of military successes in the Sino-Japanese War (1894-5), the Boxer Rebellion (1898-2001), the Russo-Japanese War (1904-5) 
and the First World War (1914-8) enhanced Japan's imperialist status and encouraged its demographic expansion into China [5].

The Japanese communities, including the concessions at the open ports, and residents were faced with the rise of nationalism among the Chinese populace after the First World War, the very first of which was the May Fourth Movement in 1919. As has been witnessed in cases in the recent years, anti-Japanese sentiment was sometimes expressed in more radical ways than demonstrations, strikes and boycotts of Japanese products, with Japanese residents and their assets sometimes being pitched into the storms of flaming animosity. In the midst of the Northern Expedition launched by Chiang Kai-shek, when the National Revolutionary Army entered Hankou and Jiujiang, revolutionary soldiers and local mobs broke into and seized the British concessions in the lower Yangzi open port cities in January 1927. A few months later, the same fate awaited the Japanese communities in the lower Yangzi area. In March, soon after the revolutionary army entered Nanjing, the Japanese and some foreign consulates and residents became the targets of vandalism and looting. In April, the Japanese residents were plunged into a similar situation as those that the British had faced one month previously in Hankou, from which most of them had to evacuate, and all but a dozen Japanese residents, scared of hostile local sentiment, left Hangzhou [6]. In May 1928, a clash between the Japanese and revolutionary forces occurred in Jinan on the Shandong Peninsula. More than one thousand several hundred Japanese residents evacuated from the city; a dozen of the remaining residents were massacred, and hundreds suffered physical assaults and damage to their assets [7].

For the Japanese communities and residents, the turbulence continued into the early 1930s. As a whole, the Japanese population continued to increase on the Chinese continent, including in Manchuria. In September 1931, the plot by the officers of the Guangdong Army ignited the Manchurian Incident. The Japanese occupation of the whole of Manchuria and the establishment of the Manchukuo in the following year opened a way for massive emigration from Japan and Korea. On the other hand, in Beijing, for example, the outbreak of the Manchurian incident led to the evacuation of Japanese residents from the city or Northern China. In Shanghai, despite the closing down of more than $90 \%$ of the Japanese spinning mills because of the military clash between the Japanese and Chinese forces in the city in January 1932, the Japanese population in the city continued to expand. The largest Japanese community in China at that time seemed to be more sensitive to the local and international economic conditions [8]. As a matter of fact, the $10 \%$ decline of the communal population between 1929 and 1930 coincided with the outbreak of the Great Depression and the other decline between 1934 and 1936 also coincided with the so-called Shanghai financial crisis [9].

The outbreak of the Marco Polo Bridge Incident in July 1937 marked a new phase of Japanese demographic expansion in China. In more detail, the influx of Koreans had already occurred in Northern China along with the progress of the Japanese plot to separate the five northern provinces from the control of the Nanjing Nationalist Government and the establishment of pro-Japanese puppet regimes in the preceding years. A series of Japanese victories and the expansion of occupation territories since the Marco Polo Bridge Incident induced the flood of newcomers from Japan, Manchukuo, and the Korean Peninsula [10]. As a result, for example, the Japanese population, including the non-Japanese ethnic minorities who were also Japanese nationals at that time, increased from 23,672 in 1937 to 103,968 in 1943 in Shanghai [9]. Although the exact number is still in question today, over two million Japanese nationals inhabited the Chinese mainland and Manchukuo when the Japanese colonial empire collapsed in the summer of 1945 [11].

\section{JAPANESE ELEMENTARY SCHOOLS IN CHINA}

Modern Japan attached great importance to "national education (kokumin kyoiku)" as an engine for modern nation-building, and the government never disregarded overseas compatriots [12]. The purpose of the educational policy in relation to the overseas Japanese was to foster or preserve their identity as imperial subjects (shinmin), encouraging the imbibing of the Japanese spirit and a consciousness of their mission to uphold Japan's national dignity and prestige overseas [13]. The Japanese residents in China also regarded educational affairs as issues of primary concern - and as headaches because of the heavy financial burden. Their earnestness to give their children a "good" education was for example quite evident in the fact that the Japanese communities were by no means frugal when it came to educational expenses which constitutively accounted for around or even much more than $50 \%$ of their annual budgets [14].

The increase of overseas Japanese residents and communities ran parallel with the increase of the Japanese population, and enrollments for Japanese schools in China also increased along with more schools being founded in China. The earliest case was an early modern terakoya-type of private tutoring school, named Honganji Ikueido, which had a branch office of Higashi Honganji - the head temple of one of the two major sects of Shin Buddhism in Japan - and opened for Japanese children in Shanghai in 1877 [15].

After the Japanese victory in the Sino-Japanese War, the establishment of concessions and the rise of non-concession type of settlements accompanied the increase of school age children, who either moved from Japan and its overseas territories such as Korea and Taiwan, or were born in China. In the midst of threatening anti-Japanese actions during the late 1920s and early 1930s, some Japanese communities went through depopulation, and a decline in enrollment at the schools in those areas followed. However, despite this decline in a few areas, as a whole, the number of schools and the enrollments continued to increase. Furthermore, with the increase of the number of overseas children and their growth, demand for education beyond the six-year compulsory education limit increased, and a variety of educational institutions ranging from kindergartens to colleges sprung up [14].

The Japanese government classified the coeducational elementary schools, along with the gender-segregated 
secondary schools -- boy's middle school (chuto gakko) and women's higher school (koto jogakko) -- into the "overseas authorized schools (zaigai shiteiko)" and "overseas unauthorized schools (zaigai mishiteiko)." The authorization was granted by the Ministries of Foreign Affairs (hereafter referred as the Foreign Ministry) and the Ministry of Education pursuant to the enforcement order of the Pension Law. The order issued in 1907 stipulated that the teachers of the authorized schools and their family members could enjoy rights equivalent to their counterparts at home regarding a retirement allowance, a pension and a survivor benefit. For those having prior teaching experience as certified teachers in Japan, their term of overseas appointment would be added to the total service years which would determine the sum of the money they should receive [16]. When Imperial Japan surrendered to the Allied Powers in the summer of 1945, there were 678 certified Japanese schools, including 215 in Manchukuo and 463 in the rest of China. Except for eight boys' middle and women's higher schools, the rest of them were elementary schools, and unauthorized schools, all of which were elementary - these would further increase the total number of Japanese educational institutions in China [17]. As a result of massive influx of newcomers after the Marco Polo Bridge Incident in 1937, some schools in major cities, such as Beijing, Shanghai Qingdao and Tianjin, became gigantic, having multiple locations enrolling thousands of students. For example, Tianjin originally had a single elementary school, which multiplied to six separate locations, and Shanghai got even more, namely eleven elementary schools, including a branch school (bunkyojo) [18].

The management of the elementary schools was left to each of the Japanese communities. More precisely, the Residents' Corporation (Kyoryumindan), was a self-governing body for overseas Japanese subjects prescribed by the Residents' Corporation Law (kyoryu mindanho) or Residents' Association (Kyoryuminkai) under the jurisdiction of consulates [19]. The school curriculum was drawn up in basic accordance with the teaching guidelines fixed by the Ministry of Education essentially for home schools, and the overseas students were more or less taught with the same textbooks which the pupils of the same generation used at home. The authorized schools were obliged to stay faithful to the guidelines introduced by Tokyo, though local circumstances required the modification of the domestic curriculum and some additional programs such as Chinese language courses [15]. The operation costs of the schools were met from tuition fees, donations from local individuals and businesses, voluntary membership fees for the Residents' Associations, and a kind of compulsory "tax" payment (kakin) by the residents - both Japanese and non-Japanese citizens - living under the jurisdiction of the Residents' Corporation. However, since education costs were a chronic heavy burden, school management had to depend on government subsidies [15].

The Japanese communities in China consisted of a multiplicity of people in terms of social stratification and ethnicity. In Shanghai, for example, the Japanese residents did not necessarily either live in a single residential area or share the same identity. Those who were called or identified themselves as "corporation group (kaishaha)" tended to be temporarily resident and live in the ex-British concession area of the International Concession and be economically more affluent than others. Those who were called "settler group (dochakuha)" chose Shanghai or China as a final abode and tended to live in the Hongkou district [20]. Occupational differences also divided the Japanese residents into different groups. A small number of high-ranking government officials and branch chiefs of trading firms and banks constituted the elite class, while employees in trading and manufacturing firms, small shopkeepers and any kind of service industry, factory hands, and the unemployed belonged to the middle and lower classes. Local Japanese entrepreneurs may also be categorized into the elite class in terms of their social status and economic affluence [21]. Newcomers after the mid-1930s, who included fortune-seekers, tended to belong to the lower class. A similar situation could be found in other Japanese communities [15]. Further complicity of the Japanese communities was due to their ethnic makeup. As was the Japanese empire itself, the overseas Japanese communities were multiethnic and multicultural, containing not only Japanese, Koreans, Taiwanese and some local Chinese. In terms of the membership of the Residents' Corporations or Associations, the Japanese were usually in the majority. One of the rare exceptional cases was in Amoy where the Taiwanese population outnumbered other communities significantly [15]. In Beijing, Koreans temporarily surpassed the Japanese in the mid-1930s as a result of the influx of a considerable number of Koreans to the northern Chinese provinces in parallel with Japan's North China Buffer State Strategy subsequent to the Manchurian Incident. Such a mosaic or salad-bowl situation caused the Japanese residents to have different class consciousness and even internal discord between different social and ethnic groups [15].

Overseas Japanese schools tended to be microcosms of the Japanese communities in which they were located. In smaller communities, the children with different backgrounds studied together. However, for example, in the case of Nanjing, despite the presence of a decent number of Korean residents, the enrollment records of the Japanese elementary school revealed that Korean children did not attend the school despite their presence in the city as evident in another Japanese record. In the larger communities, the children of the elite families tended to concentrate in the same schools. In Shanghai, many children of the elite families belonging to the "corporation group" went to the 2nd Northern Japanese Elementary School (Daini Hokubu Nihon Jinjo Shogakko) founded in 1939, renamed the Fifth National School (Daigo Kokumin Gakko) as a result of the enactment of the Imperial Edict on National Schools (Kokukin Gakkorei) two years later. For this reason, the Japanese residents called the school the "Peers School of Shanghai (Shanhai no Gakushuin) [22]." In Beijing, Beijing City North National School (Pekin Johoku Kokumin Gakko), separated from another school in 1941 and seemed to enroll more children of better educated well-to-do families than other schools [23]. The psychological gap which derived from class consciousness seemed also to be shared among the students. An ex-student, from an affluent Japanese family, in the elementary school in 
Tianjin witnesses that he and his schoolmates with equivalent family backgrounds viewed Japanese and Korean newcomers who flowed into the Japanese concession area in the late 1930 s and early 1940s as poor and rough heterogeneous people [24]. In such circumstances, the school administrators had to devise how to deal with students with different familial, cultural and ethnic backgrounds, as well as sometimes different languages [25].

\section{THE NORTHERn CHINA JAPANESE SCHOOL PRINCIPALS' CONFERENCE (1926-1942)}

Engagement in education for overseas children (kaigai shijo kyoiku) seems to be a challenge attended with arduous tasks. The Ministry of Foreign Affairs (MOFA), which is in a position to cooperate with MEXT regarding overseas education today, understands that it is "one of the primary concerns for overseas nationals," recognizing the improvement and enhancement of education for overseas Japanese children as quite a significant necessity for the further success of Japanese overseas activities [3]. However, today, those concerned with educational administration and overseas educational institutions consider Japanese overseas education to be confronted with a number of problems. For example, under his temporary transfer to MEXT as Director, International Education Division, Nakai Kazuhiro, a MOFA official, noted in 2012, "Japanese overseas education was at the crossroads [2]." Years before then, a MEXT official also pointed out that the supplementary Japanese schools, at which about a quarter of all the overseas Japanese children of compulsory education age (6-15 years old) were in attendance, were in a "transitional period [2]."

In the mid-1920s, those engaged in the management of the Japanese schools in China seemed to have come to a joint conclusion that something should be done with regard to the situation of overseas education, at least in China. In the joint bill submitted by the four elementary schools in Qingdao to the aforementioned First North China Elementary School Principals' Conference in Beijing they deemed overseas education to be in stagnation (teitai) [26]. In the opening ceremony of the first conference in August 1926, the principal of the Beijing Japanese Elementary School Hirota Haruaki confessed that his eight year service in the position had caused him much anguish (modae), describing the conference as the meeting of the principals who shared this distress (urei) and who sought for a solution to overcome the problems which their schools were confronted with [27]. Those terms, such as "stagnation", derived perhaps from the problems as discussed in detail below, which the executive school administrators had perceived in their schools.

Desire for this sort of gathering was in fact not confined to northern China. In December 1925, the principal of Shanghai Japanese Elementary School, Hasegawa Keitaro, petitioned the Japanese consulate at Shanghai for a conference of the principals of the authorized schools in southern China and in the Yangzi River valley. After appealing with regard to the difficulty of attending the annual principals' meeting, sponsored by both the Ministry of Education (present-day MEXT) and the Imperial Society for Education (Teikoku Kyoikukai) founded in 1896, the principal continued that such an opportunity only for overseas school, which should not be discussed in the same way as the domestic counterparts, would be necessary for educational improvement [28]. The Consul-General took the petition, asking his superior, Foreign Minister Shidehara Kijuro, to cover the travel expenses of the participants and to dispatch an official from the education and foreign ministries to the conference, as he considered this to be conducive to national interests - though no records indicate that the conference actually took place [27].

The setting up of the conference in 1926 was largely thanks to the efforts of Hirota Haruaki. As a matter of fact, a similar event took place in Beijing in 1912, though its details and reasons for discontinuation are unknown [27]. After more than ten years had passed, it was the Beijing Elementary School that called for the conference, with the consent of its management body, namely the Beijing Japanese Residents' Association (Pekin Nihon Kyoryuminkai) and the approval of the Japanese legation. In the opening ceremony of the First North China Elementary School Principals' Conference on August 2, Lieutenant General Banzai Rihachiro, who was the advisor to the Beijing Government and the Vice President of the local Japanese Residents' Association, praised Hirota for his contribution to the materialization of such a gathering [9]. Hirota himself stated that the beginning of the story could be traced back to 1924 when one day that year he had a chance to meet the principals of a few other schools and proposed the conference. They favored his idea, but those top school administrators simultaneously recognized that some difficulties, including securing of resources, would arise on the route toward the materialization of the conference. Probably at the very beginning of September 1925, Hirota appealed for the necessity of the conference and won the support of the Minister of Japan to China, Yoshizawa Kenkichi, who promised to make efforts to obtain financial support from the Foreign Ministry despite fiscal austerity at home. By the beginning of March 1926, twelve schools, including the Zhifu Elementary School who had originally been left out of the invitation list, had decided to participate in the conference which was scheduled for March 25 to 27 [27]. The Foreign Ministry had decided to provide 2,500 yen to cover the participants' traveling costs and Beijing's hosing expenses and, along with the Education Ministry, to dispatch officials to Beijing [27].

However, Hirota and other organizers of the conference had to wait for four more months to reach the opening day. China was still in the midst of a civil war situation and the Tianjin-Pukou (Jinpu) Railway, which the participants would have to use to come to Beijing, was paralyzed between Tianjin and Jinan at the very beginning of March. Yoshizawa then reported to Tokyo on March 9 that the conference was postponed. In April, another part of the railway, between Beijing and Tianjing was also disrupted. The Japanese minister made another dispatch to Tokyo on May 14, reporting that the conference was rescheduled for August 2 to 4 [27]. The operation of the railway was restarted in July, and the attendees of the conference, including the representatives of the twelve schools whose scale varied in enrollment from over one thousand at First Qingdao Elementary School to merely 15 at Boshan Elementary School, finally saw the first 
opening day in the small auditorium of the Beijing Elementary School on August 2. After a series of discussions and lectures, the conference was closed with the adoption of a resolution on August 4 [27].

The entrant schools and their nearby Japanese missions expected the conference to be held yearly, and the Foreign Ministry gave sanction to the regular holding; in reality, it was not possible to continue to open on a regular basis in the middle of the constant aggravation in Sino-Japanese relations toward the end of the 1920s and throughout the 1930s. The second conference was hosted by the Qingdao Japanese Residents' Corporation (Chintao Nihon Kyoryumindan) early in August 1927 [29]. The overseas Japanese residents wanted to have such gatherings to exchange and share know-how, opinions and problems, but subsequent conferences were no longer held on a regular basis. The third conference was originally scheduled to be brought to Tianjin in October 1928, but was not held until August 1929. Another railroad disruption between Tianjin and Jinan caused by the military clash between the Japanese Imperial Army and the Chinese revolutionary forces led by Chiang Kai-shek (Jiang Jieshi), known as the Jinan Incident, took place at the very beginning of May 1928. The fighting was over with the Chinese evacuation from the walled city on the Shandong Peninsula and the subsequent Japanese occupation of the walled city on the Shandong Peninsula in slightly more than a week, but the continued threatening situation to the local Japanese residents prolonged the postponement. Furthermore, some schools requested that the conference should take place during the summer vacation rather than in the middle of the school term [30]. In the 1930s, tension between China and Japan continued to increase, especially after the Manchurian Incident in 1931, and five years passed until the fourth conference took place in Jinan in August 1934 [31]. The Japanese schools continued to schedule the conference in Tianjin and Zhifu in the following two years, but neither plan was implemented [32].

The loss of the support from Tokyo became another cause preventing the annual holding of the conference. After the conference had taken place three times, in June 1931, Foreign Minister Shidehara refused to support the annual holding for three reasons. First, he deemed that enough discussion had taken place during the previous conferences. Second, the educational effect of the conference was not particularly recognized. Third, since more overseas schools had demanded an increase in subsidies, it would be difficult to maintain the same amount of financial support as in previous years. In July 1936, admitting the usefulness of the conference, Foreign Minister Arita Hachiro stated that the ministry intended to introduced the principle of holding the conference at three to five year intervals, giving the same reasons as Shidehara for doing so [32]. However, the conference was not held thereafter, not even every three or five years. It is unknown whether the Foreign Ministry actually planned to hold subsequent conferences in the late 1930s; no matter what the ministry intended or did not intend to do, the local conditions in China would not have enabled the Japanese to continue the conference. In July 1937, the Marco Polo Bridge Incident broke out, and Japan and China entered an all-out war called the Sino-Japanese Conflict or the Second Sino-Japanese War. As a result, it was not until May 1942 that the fifth - and last before the end of the Second World War - conference came back to Beijing [33].

\section{The Issues Discussed AT THE CONFERENCES}

The detailed minutes of every conference were published as the proceedings of the North China Principals' Conference, which are in existence today, except for the proceedings of the fifth conference, and they reveal how the conferences were organized and what topics were discussed. In the case of the first conference in 1926, the Foreign Ministry first suggested three inquiries as noted below. Each entrant school also submitted written proposals for agenda items to the host school in Beijing, and the Japanese legations issued the copies of the proposals to the Foreign Ministry in advance before the conference took place in August. On day one of the three day conference, the principals of the twelve entrant schools were divided into three committees, each of which discussed one of the three inquires. The issues brought by each school were categorized into four groups, which were also discussed in four different committees consisting of the principals. On day two, each of the seven committees drafted reports, which all the participants deliberated on together. On the final day, the conference approved the replies to the Foreign Ministry on the three inquiries, proposals and resolutions to the Foreign Ministry, and agreements between the entrant schools. The subsequent conferences were organized more or less along these lines [27].

The three inquiries which the Foreign Ministry suggested virtually set up the directions of discussion during the first conference. On March 1 1926, about three weeks before the originally scheduled conference date, in a dispatch to Beijing, Foreign Minister Shidehara instructed that the conference should reply to the following [27]:

- What should be especially considered in overseas education in comparison to the domestic education?

- What measures should be employed to foster the children's national consciousness and patriotism?

- What aspects of overseas education should be improved in the future?

These inquiries were indeed by no means misdirected in terms of the concerns which the entrant schools actually had at that time. This is probably because the ministry had already grasped the state of the Japanese schools in China; the Foreign Ministry had received a report entitled "The Outline Concerning the Improvement of Overseas Educational Institutions" from Ogawa Tadaatsu, who was the attaché of the ministry and made an inspection tour of China in 1925. The problems and proposals which Ogawa, who had a career as an educator, pointed out and made in the report corresponded to those that the principals of the entrant schools made during the first conference as discussed below [27].

As the replies to the first and third inquiries, the conference detailed the features and issues found in and unique to the Japanese schools in northern China, which can be classified into the following three categories. First, the problematic propensities of the Japanese school children were enumerated as follows [27]: 
- Many overseas Japanese school students were ignorant of their own country, which tended to make it difficult for them to understand the contents of the curriculum.

- Many cases of students being moved into or withdrawn from school during the middle of a term made it difficult for the schools to pursue thorough instruction.

- The Japanese residents in China tended to lead a luxurious life and spend excessively on their children's school supplies and other products.

- The students generally lacked steadiness and tenacity.

- The students did not have enough opportunities to undertake physical exercise and tended to dislike manual labor.

- In comparison to their fellow nationals, the students lacked piety and respect for their ancestors.

Second, the problems recognized extensively among the Japanese residents, who included the parents of the school children, were pointed out [27]:

- Living together with foreigners, the Japanese residents were sometimes insulted by or had friction with them.

- The overseas residents' strong sentiment toward their country sometimes led to blind, narrow-minded patriotism (modo henkyo no aikokushin).

- The disposition of the overseas residents, because of their lack of steadiness and their indolence, led to relative inferiority in physical strength compared to foreigners.

Third, the problems which the Japanese education in China had were discussed [27]:

- The absence of educational guidelines left overseas schools to educate in their own fashion and this would hamper overseas expansion as a primary state policy.

- The educators in China also tended to be contaminated easily by the local residents' aforementioned unfavorable disposition.

The conference also discussed the handling of the abovementioned situations and phenomena in relation to Japanese schools. In order to rectify the students' unfavorable disposition, the following measures were suggested [27]:

- A school excursion (shugaku ryoko) to Japan and the use of such audiovisual aids as films on Japan, radio programs and the exhibition of domestic artifacts would be beneficial to help the students understand their own national identity.

- The same curriculum, textbooks and teaching materials as those used in the schools in Japan should be used to teach the students who might enter or leave half way through a term in order to ensure consistency.

- The simple life should be recommended, and the schools should select more practical school supplies.

- The schools should take a strict stance on students' lax behavior, they should pay attention to health, and put more emphasis on physical training in order to foster their fortitude. The students should also be assigned to take care of the school yard and participate is housekeeping at home.

- Since they lived together with foreigners, this should provide a convenient environment for fostering the students' cosmopolitan spirit, and schools should try to cultivate a sense of mutual affection through constant contact with foreign children.

- Since living in China was deemed to be advantageous to understanding the country, the cultivation of students' self-awareness of their mission to play a pivotal role in the future Sino-Japanese partnership was required.

- It was deemed to be necessary to cultivate the Japanese children's spirit of permanent residence by making them understand the population problem and the contribution of living overseas to national interests.

- Piety was deemed to be commendable and should be fostered by means of visits to shrines and the worship of Shinto deities and Buddha at home should be encouraged.

- A proper critical view of foreign cultures and customs should be fostered in order to make up for their own shortcomings by finding others' merits.

- More contents on China should be added to the government-designated geography and Japanese language textbooks, because the Japanese, not only in China but also at home, should deepen their understanding of the country - a matter which is of grave importance for Japan.

Suggestions to improve the Japanese communities in which the children lived and were raised in were made [27]:

- The overseas Japanese residents should be careful of their speech and behavior, and avoid being the cause of insults and clashes with foreigners.

- The overseas Japanese residents should try to avoid falling into blind, narrow-minded patriotism.

- Since the behavior of an individual overseas Japanese tends to be understood as the behavior of the entire Japanese nation, overseas Japanese residents should be dedicated to avoiding disgracing their country.

- In order to rectify the unfavorable disposition of the overseas Japanese residents, the Residents' Corporations and Associations should establish facilities for social education, such as libraries and various youth organizations, and for physical training.

Proposals and petitions for the improvement of the overseas education were set out for the Japanese government as follows [27]:

- Since overseas education is a peculiar environment, general principles of overseas education should be introduced.

- In order to establish guidelines for overseas education, considerable national expenditure would have to be assigned for the development of explicit educational facilities, such as an administrative unit for overseas education inside the Foreign Ministry and supervising bodies inside legations or in proper locations to supervise overseas teachers, institutions for training overseas teachers, and an explicit chain of different levels of educational institutions to promote the domiciliation of overseas residents.

- Japanese elementary schools in China should have closer communications and contribute to mutual support for learning and the betterment of youth.

- Overseas teachers should realize the profound importance of and be sincerely engaged in their duty with an enterprising spirit.

- Friendship and mutual study should be promoted between 
Japanese and Chinese students, as well asbetween students and teachers by creating a liaison system.

- At national expenditure level, the personnel expenses of overseas schools should be all covered for the purpose of releasing the overseas schools from fiscal difficulties, achieving the independence of teaching staff's educational authority from the Residents' Corporations and Associations which tend to treat them as employees, and upgrading the treatment of the teaching staff which would be necessary to acquire able teachers.

- At national expenditure level, boys' and girls' middle schools should be founded between Beijing and Tianjin to facilitate the overseas Japanese children, who tend to return to Japan after primary education, to stay permanently in China.

- At national expenditure level, an opportunity for an inspection tour to Japan, China, Siberia and others should be given to teachers in China as it is given to their counterparts at home.

The conference's reply to the second inquiry, resolutions and agreements furthermore included more detailed and practical measures and proposals on school administration and teaching methodologies. For example, as a reply to the second inquiry, the conference stated that fostering national consciousness and patriotism was of primary concern in each subject at the overseas elementary schools, suggesting that teaching with the same government-designated textbooks would, however, require special considerations in order to achieve the equivalent effect of domestic schools by listing specific measures on seven subjects - morals, Japanese language, Japanese history, geography, science, commerce and music. Without waiting for the government-introduced guidelines, the conference set up local educational principles and decided to establish the North China Association for Education (Hokushi Kyoikukai) as an organ to promote communications between the schools. It also decided to add Chinese language as an optional course for the students who were higher than fourth graders, and to compile a supplementary textbook to deepen students' understanding of China. Noteworthy features were agreements such as closing the schools on local holidays whenever possible to express respect for China, matriculating and treating Chinese children without discrimination, and calling the local people "Chugokujin (C. Zhongguoren)" or "Minkokujin (C. Minguoren) out of consideration for the local communities in which the Japanese schools were located. Moreover, the conference decided to introduce educational and safety measures to avoid inspiring the horror of local anti-Japanese sentiment and upheavals [27].

The principals' understanding of the state of their own schools was by no means peculiar. Most of the problems they found and discussed were what the Foreign Ministry also noticed, even before the first conference took place as seen in abovementioned inspection report by Ogawa in 1924. Based on his inspection, Ogawa in fact made very similar proposals to the conference. Ogawa confessed in the report that he felt "unendurable wrath and grief" with regard to the state of Japanese overseas education in China. What drove him to such feelings were the shortage of budget, facilities and able teachers, and the absence of centralized control and supervision over the overseas schools. Ogawa hence made the following proposals [28]:

- The Foreign Ministry should establish guidelines and instruct overseas schools through legations.

- A system of school inspectors should be introduced for overseas schools as has been instituted on the Japanese mainland and in the colonies.

- Government subsidies should be increased to improve school facilities.

- The Foreign Ministry should be more directly involved in employing able teachers for overseas schools and establishing a plan to deploy them, by which unqualified teachers should be replaced in an efficient way.

- For the same reason as above, the system to transfer teachers between the homeland and overseas schools should be established.

- Because of the exclusion from the pension law it is more difficult to employ teaching staff, therefore, unauthorized overseas schools should be encouraged to obtain the status of an authorized school so that teachers can benefit from the law.

In another inspection report, Yamauchi Yutaro made similar suggestions to the conference. In the spring of 1928, the Foreign Ministry dispatched Yamauchi Yutaro, the educational inspector (tokugakukan) of the Ministry of Education and an ex-professor in sociology at the Tohoku Imperial University, to China. Yamauchi visited various kinds of Japanese and Chinese schools in China, including some in Manchuria. He visited northern and central China, including nine authorized schools, for example, in Jinan, Tianjin and Beijing. In the inspection report, Yamauchi observed that the schools which he inspected, with some exceptions, were in stagnation (chintai). After pointing out similar problems also referred to at the conference, Yamauchi made the following proposals [28]:

- The government subsidy should be increased and the teachers' basic salary should be covered at national expenditure level.

- Teachers' status should be stabilized by giving them a status of civil servant and devise a means to facilitate the transfer of teachers between the homeland and overseas schools.

- The treatment of the teachers should be raised at least to the level of thee teachers in Korea and Manchuria.

- A means to train teachers, such as research funds, inspection tours and workshops, should be devised.

- Teacher training facilities should be established in Shanghai, Qingdao, etc.

- Officials who are familiar with educational administration should be stationed inside legations to deepen legations' understanding of teachers and to prevent the Residents' Corporations from intervening in educational affairs.

- A division or section in charge of overseas education should be instituted, and school inspectors should be permanently stationed in Shanghai, Beijing and Qingdao, and perambulate between schools.

- Supplementary texts conforming to the government-designated textbooks for overseas schools should be issued. 
The proceedings of the three other conferences in 1927, 1929 and 1934 indicate that the discussion at the first conference became the starting point for the subsequent discussions. In other words, the issues discussed in the subsequent three conferences were more or less derived from those discussed at the first conference. In the second conference in 1927, as well as the first, the three inquiries of the Foreign Ministry became the springboards for discussion. The ministry inquired about the status of the implementation of the discussions that had taken place one year before, consulting the entrant schools at the second conference on two proposals, as its response to the proposals and petitions in the first conference, on the transfer of teachers within each of the groups into which the elementary schools in China would be divided and on the establishment of combined elementary and middle schools [29]. At the third conference in 1929 , the ministry consulted on six issues, including the inquiry on the implementation of the discussions that had taken place at the second conference, the most difficult problems and measures to be taken, the fostering of national spirit (kokumin seishin), a system to transfer and train the teaching staff, and the North China Association for Education [30]. Two conferences were organized in a similar way to the first one, replying to the inquiries and exchanging opinions on the same or similar issues which had already come up during the previous occasions, but at the fourth conference in 1934 the Foreign Ministry did not seem to submit inquiries for unknown reasons [31].

In other words, the issues discussed at the first conference indeed continued to dominate the discussions in the subsequent conferences. From this fact, it may be quite understandable that the Foreign Ministry had considered that the conference had run out of further issues to be discussed in 1931, five years after the first conference took place in Beijing. From a different perspective, this might be evidence that the overseas schools' appeal for remedial measures to overcome the unfavorable state of overseas education were not easily translated into reality. In Tianjin, for example, sixth graders' excursions to Japan, which was an idea suggested in the first conference, became an established school event and continued from 1933 until its suspension months before Pearl Harbor in 1941 [34]. After the outbreak of the Sino-Japanese Conflict in 1937, the dispatch of the teaching staff from the homeland to overseas schools on their request also materialized because of the mass influx of newcomers into China, and there Japanese schools were, as a result, relieved from painstaking efforts to hire the necessary teaching staff [35]. Although the government subsidies to the overseas schools increased along with the increase of enrollment, they were never liberated entirely from struggles with fiscal difficulties. However, the twelve proposals on overseas education made by the Overseas Education Promotion Committee (Kaigai Kyoiku Shinko Iinkai), created by the Imperial Association for Education, in its first meeting on September 16, 1941 to a great extent coincided with the proposals and suggestions made at the first conference in Beijing in 1926 [36]. The same or similar proposals were repeated by the committee itself and committee member Oshima Masanori, who was also the Chief Director of the Division of International Education of the Association in the subsequent couple of years during the wartime period, whose end brought about the demise of the Japanese colonial empire and of the overseas Japanese schools, in an about couple of more years [37].

There is no direct evidence on the specific reasons why educational improvement was not realized to any great extent, but some hypothetical explanations may be possible: as some who dealt with the Japanese schools doubted the efficacy of the conference to cope with the problems, the petition type of politics could not have been effective without sufficient support at official and unofficial levels, especially at home. Some at home had been aware of the problems involved in overseas education almost simultaneously with the Japanese schools in China. Nagata Shigeshi, the president of Nippon Rikkokai, an organization founded in 1897 supporting Japanese emigrants and struggling students, and the abovementioned Oshima who was the Director of Tokyo Education Bureau at that time, contributed articles to the journal of the organization Rikko Sekai in 1927, pointing out the same problems as those discussed at the conference in Beijing. Nagata simultaneously in the same articles pointed out the general indifference to overseas education. Environed by such an atmosphere, overseas education possibly could not gain a higher priority on the governmental agenda [38]. Even having recognized the importance of overseas education in terms of national interests, during the times of domestic and external crises the government could not have afforded to spend extra resources on the education of overseas children who only accounted for a small percentage of the children of the same ages. For example, a bill to introduce the position of school inspector (gakumukan) to overseas education passed in the Imperial Diet in March 1927, but did not lead to enforcement before 1945 [14].

\section{CONCLUSION}

The North China Japanese School Principals' Conference which began for the purpose of the betterment of education for overseas Japanese children in Northern China had the following significance. First, the conference initiated by the local Japanese educators and residents clarified the problems which the overseas schools faced, at least in Northern China, in the late 1920s and1930s. Second, this was pioneering work in China, and similar kinds of meetings of Japanese school administrators and managers of different levels and in different areas followed. Third, the effort to commence and continue such event, despite the unsettled local sociopolitical conditions, manifested the overseas Japanese residents' deep concern over education for their children and the educators' zeal for and devotion to educational betterment.

Nevertheless, the conference simultaneously had limitations in terms of the materialization of its objectives. The local conditions and the tense Sino-Japanese relations did not allow for the Japanese schools to hold the conference annually despite their expectations. The conference continued to be pushed hither and thither by those prevailing conditions and had to be repeatedly postponed and cancelled from the very beginning. The collective efforts of the overseas Japanese schools were not enough to overcome the general atmosphere of indifference and gain more attention and administrative and financial support for overseas education.

Finally, the experiences of the conference in the pre-1945 
decades may carry significance for current Japanese overseas education. As a matter of fact, postwar Japanese overseas education is being confronted with some of the same problems the entrant schools of the conference had around seventy or eighty years ago. The current dispatch system is unable to supply enough teachers to overseas schools. Whereas the system of dispatching licensed teachers was introduced in the early 1960s, many Japanese educational institutions at elementary school level are being managed merely by the local steering committee and locally-employed teachers without dispatched teachers [14]. Despite annual governmental subsidies, the fiscal constraints and fragility of the system are by no means a story of the past [39]. The experiences of the Japanese schools, including the discussions and suggestions made at the conference, may still be worth the attention of today's government and educators.

\section{REFERENCES}

[1] T. TaKi, Kaigai haken kyoshi e no michi, Tokyo: Soyusha, 2008, pp. 70-74.

[2] Kikyusen: kaigai shijo kyoiku dayori. [Online]. Available: http://www.mext.go.jp/a menu/shotou/clarinet/004/003/1288937.htm

[3] Kaigai shijo kyoiku. [Online]. Available: http://www.mofa.go.jp/mofaj/toko/kaigai/kyoiku/

[4] N. Mizuno, "The Japanese Overseas Education: Its Current State and Problem," International Proceedings of Economics Development and Research, vol. 64, pp. 45-50, 2013.

[5] M. R. Peattie, "Japanese Treaty Port Settlements in China, 1895-11937," in The Japanese Informa Empirr in China, 1895-1937, Peter Duus and Mark R. Peattie EDS, Princeton, NJ: Princeton University Press, 1989, pp. 169-170.

[6] C. H. Rengokai, Nankin Kanko jiken shiso: Yosuko ryuiki hojin ryuiki jikki, Tokyo: Okada Nichieido, 1927.

[7] S. Honbu, Showa 3-nen Shina Jihen shuppeishi, Tokyo: Gannando, 1971.

[8] Z. Chen, "Seiyo Shanhai to Nihonjin kyoryumin shakai," in Chugoku ni okeru Nihon sokai: Jukei, Kanko, Koshu, Shanhai, Tokyo: Ochanomizu Shobo, 2006, pp. 224

[9] H. Fujita, "'Kokusai toshi' Shanhai ni okeru Nihonjin kyoryumin no ichi: sokai gyosei tono kankei o Chushin ni," Ritsumeikan gengo bunka kenkyu, vol. 21, no. 4, pp. 122, 2010.

[10] Zaigai Nihonjin gakko kyoiku kankei zakken zaigai Hokushi no b: Pekin kaku Nihon kokumin gakko dai 2-kan 2 (The miscellaneous matters on the education of the overseas Japanese schools on north china: north china Japanese national schools in Beijing), vol. 2, no. 2 , The Ministry of Foreign Affairs, Tokyo.

[11] T. Fujimura. (1998). Nenpyo Chugoku kikokusha mondai no rekishi to engo seisaku no tenkai. Kiyo. [Online]. Available: http://www.kikokusha-center.or.jp/resource/ronbun/kiyo/06/k6_12.pd f.

[12] The preamble of the 1872 Ordinance of the State Council on Education. [Online].

Available: http://www.mext.go.jp/b_menu/hakusho/html/hpbz198102/hpbz1981 $02 \quad 2 \quad 012 . \mathrm{html}$

[13] M. Kojima, Nihonjin gakko nokenkyu: Ibunnkakan kyoikushiteki kosatsu, Tokyo: Tamagawa Daigaku Shuppanbu, 1999, pp. 18, 36-55.

[14] Zaigai Nihonjin gakko kyoiku kankei zakken: zaigai teikoku kyoryumindan oyobi minkai kankei zassen, The miscellaneous matters on the education of the overseas Japanese schools: the overseas residents' corporations of the empire and the miscellaneous matters, The Ministry of Foreign Affairs, Tokyo.

[15] M. Kojima, Nihonjin gakko nokenkyu: Ibunnkakan kyoikushiteki kosatsu, Tokyo: Tamagawa Daigaku Shuppanbu, 1999, pp. 267.

[16] Zaigai shitei gakko shokuin taiin oyobi izoku fujoryo: Onkyuho o sadamu (The laws on the retirement, bereaved family's welfare payment, and pension of the staff of certified overseas schools have been enacted), The Cabinet of Japan, Tokyo, 1905

[17] T. Takao, Kaigai haken kyoshi e no michi, Tokyo: Soyusha, 2008, pp. 72.

[18] M. Kojima, Nihonjin gakko nokenkyu: Ibunnkakan kyoikushiteki kosatsu, Tokyo: Tamagawa Daigaku Shuppanbu, 1999, pp. 268

[19] Kyoryumindaiho, The law on the residents' corporation, The Cabinet of Japan, Tokyo, 1907.
[20] H. Takatsuna, Kokusai toshi Shanhai no naka no Nihonjin, Tokyo: Kenbun Shuppan, 2009. pp. 28-69.

[21] M. Matsumura, "1930-nendai ni okeru Tenshin Nihon sokai kyoryumin shakai no kozoteki tokushitsu Kaiko toshi kenkyu," vol. 6. pp. 73-90, May 2011.

[22] Takatsuna Hirofumi, Kokusai toshi Shanhai no naka no Nihonjin. Tokyo: Kenbun Shuppan, 2009, pp. 123-124.

[23] I. Ogawa, Pekin no Nihonjin gakko: Pekin Johoku Nihon Kokumin Gakko shi. Tokyo: Chobunsha, 1994, pp. 23-24.

[24] T. Yagi, Tenshin no Nihon shonen, Tokyo: Soshisha, 1997, pp. 216-217.

[25] M. Nishimura, Tenshin Nihon sokai monogatari, Takaishi-shi: Eiho Shinto Yukan, 1997, pp. 193-194.

[26] Zaigai Nihonjin gakko kyoiku kankei zakken: kokumin gakkocho kaigi kankei 4 Showa 3-nen, The miscellaneous matters on the education of the overseas Japanese schools 4 1928, The Minsitry of Foreign Affairs, Tokyo, 1928.

[27] Zaigai Nihonjin gakko kyoiku kankei zakken: kokuminn gakkocho kaigi kankei 2 Taisho 15-nen bunkatsu 1, The miscellaneous matters on the education of the overseas Japanese schools: concerning the national school principals' conference 21926 prt. 1, The Ministry of Foreign Affairs, Tokyo, 1926.

[28] Zaigai Nihonjin gakko kyoiku kankei zakken: dai 1-kan 2: Chugoku bunkatsu 2, The Miscellaneous matters on the education of the overseas Japanese schools vol. 1 no. 2: China prt. 2, The Ministry of Foreign Affairs, Tokyo, 1924.

[29] Zaigai Nihonjin gakko kyoiku kankei zakken: kokuminn gakkocho kaigi kankei 3 Showa 2-nen, The miscellaneous matters on the education of the overseas Japanese schools: concerning the national school principals' conference 3 1927, The Ministry of Foreign Affairs, Tokyo, 1927.

[30] Zaigai Nihonjin gakko kyoiku kankei zakken: kokuminn gakkocho kaigi kankei 5 Showa 4-nen, The miscellaneous matters on the education of the overseas Japanese schools: concerning the national school principals' conference 5 1929, The Ministry of Foreign Affairs, Tokyo, 1929.

[31] Zaigai Nihonjin gakko kyoiku kankei zakken: kokuminn gakkocho kaigi kankei 8 Showa 9-nen, The miscellaneous matters on the education of the overseas Japanese schools: concerning the national school principals' conference 8 1934, The Ministry of Foreign Affairs, Tokyo, 1934.

[32] Zaigai Nihonjin gakko kyoiku kankei zakken: kokuminn gakkocho kaigi kankei 10 Showa 11-nen, The miscellaneous matters on the education of the overseas Japanese schools: concerning the national school principals' conference 10 1936, The Ministry of Foreign Affairs, Tokyo, 1936.

[33] Zaigai Nihonjin gakko kyoiku kankei zakken: kokuminn gakkocho kaigi kankei 14 Showa 17-nen. The miscellaneous matters on the education of the overseas Japanese schools: concerning the national school principals' conference 14, 1942, The Ministry of Foreign Affairs, Tokyo, 1942.

[34] M. Nishimura, Tenshin Nihon sokai monogatari, Takaishi-shi: Eiho Shinto Yukan, 1997, pp. 78-79.

[35] Zaigai Nihonjin gakko kyoiku kankei zakken dai 6-kan 3: Chugoku bunkatsu 2, The Miscellaneous matters on overseas Japanese schools vol. 6, no. 3, The Ministry of Foreign Affairs, Tokyo.

[36] M. Kojima, Dai 2-ji Sekai Taisen zen no zaigaai shitei kyoikuron no keifu, Kyoto: Ryukoku Gakkai, 1993, pp. 140-141.

[37] M. Kojima, Dai 2-ji Sekai Taisen zen no zaigaai shitei kyoikuron no keifu, Kyoto: Ryukoku Gakkai, 1993, pp. 158-159.

[38] M. Kojima, Dai 2-ji Sekai Taisen zen no zaigaai shitei kyoikuron no keifu, Kyoto: Ryukoku Gakkai, 1993. pp. 9-14, 60.

[39] N. Mizuno, "The Japanese Overseas Education: Its Current State and Problem," International Proceedings of Economics Development and Research, vol. 64, pp. 50, 2013.

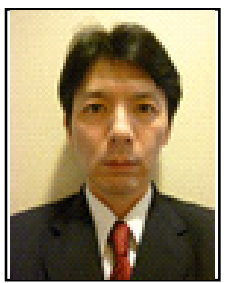

Mizuno Norihito is an associate professor in the global studies program at Akita International University, Akita, Japan. He was born in Nagoya, Japan and graduated from the Faculty of law of Keio University, Tokyo, Japan. He earned Ph.D. in history at the Ohio State University, Columbus, OH, USA. His field of specialty is Japanese-East Asian relations, especially Sino-Japanese relations. He is currently working on Japanese communities and educational institutions in China during the modern period. 